\title{
Perkembangan Teknologi E-Bussiness
}

\section{Basteo $^{1}$}

${ }^{1}$ Faculty Of Computer Universitas Mitra Indonesia

basteo.student@umitra.ac.id

\section{PENDAHULUAN}

Pendekatan Keilmuan Computer Science menjadi rujukan dalam implementasi Produk Teknologi. Penerapan Sistem Informasi menjadi hal yang sangat fundamental (Febriani \& Putra, 2013) . Penggunaan penerapan teknologi dimasa sekarang dan masa mendatang menjadi hal yang sangat penting dalam perkembangan intelegensia Technology (Putra \& Febriani, 2017). Produksi aplikasi berbasis Humanity membuat aplikasi berkembang dengan sangat cepat, sisi efektifitas dan sisi efisiensi menjadi hal yang sangat berperan dalam perkembangan teknologi tersebut (Putra et al., 2018). Sehingga factor dalam pencarian keterbaruan ataupun novelty menjadi hal yang harus dikembangkan diberbagai lini (Putra et al., n.d.).

\section{PERTANYAAN-001}

Berisi deskripsi tentang pertanyaan yang dilontarkan oleh Bpk. Dr. ( c ) Arie Setya Putra, CA, S.Kom, M.T.I ; Menurut anda Seberapa Penting Teknologi informasi yang meliputi segala alat maupun metode yang terintegrasi untuk digunakan dalam menjaring atau menangkap data (capture), menyimpan (saving), mengolah (process), mengirim (distribute), atau menyajikan kebutuhan informasi secara elektronik ke dalam berbagai format, yang bermanfaat bagi pemakai (user) khususnya dalam perkembangan e-commerce dalam bisnis, berikan contoh konkritnya menurut anda? 


\section{HASIL JAWABAN}

Jabarkan Jawaban Anda : Semakin maraknya sekarang terhadap perkembangan jaman melalui media sosial atau pun aplikasi-aplikasi yg sangat mempermudah berbelanja kebutuhan pokok maupun kebutuhan sekunder tidak lain dan jauh dr adanya perkembangan teknologi informasi seperti contohnya adanya google play, shoppe, dan masih banyak yg lainnya

\section{DAFTAR REFERENSI}

Febriani, O., \& Putra, A. (2013). Sistem Informasi Monitoring Inventori Barang Pada Balai Riset Standardisasi Industri Bandar Lampung. Jurnal Informatika Darmajaya, 13(1), 90-98.

Putra, A. S., \& Febriani, O. M. (2017). Knowledge Management Online Application in PDAM Lampung Province. International Conference on Information Technology and Business (ICITB), 1, 181-187.

Putra, A. S., Febriani, O. M., \& Bachry, B. (2018). Implementasi Genetic Fuzzy System Untuk Mengidentifikasi Hasil Curian Kendaraan Bermotor Di Polda Lampung. SIMADA (Jurnal Sistem Informasi Dan Manajemen Basis Data), 1(1), 21-30.

Putra, A. S., Sukri, H., \& Zuhri, K. (n.d.). Sistem Monitoring Realtime Jaringan Irigasi Desa (JIDES) Dengan Konsep Jaringan Sensor Nirkabel. IJEIS (Indonesian Journal of Electronics and Instrumentation Systems), 8(2), 221-232. 